\title{
Improvement in the Shelf-life of Japanese Strawberry Fruits by Breeding and Post-harvest Techniques
}

\author{
Minori Hikawa-Endo*
}

Western Region Agricultural Research Center, NARO, Zentsuji 765-8508, Japan

\begin{abstract}
Japanese strawberries have quite high palatability, as well as softness, making them a valuable commodity for local consumption and export. To preserve these characteristics, several unique efforts have been made to improve the shelf-life of strawberry fruits in Japan. This review summarizes the specific breeding and technological developments currently in practice to distribute Japanese strawberries without losing palatability while prolonging the shelf-life. With respect to breeding, the amount and ratio of hydrochloric acid-soluble pectin have been improved, including the hydrochloric acid-soluble pectin to holocellulose ratio, which is related to fruit texture. In addition, although the optimal fruit shape is uncertain, the apex and equatorial parts can be bred to be more rounded in some new varieties. Inflorescence characteristics have also been improved to increase the uniformity of fruit shape and size, which can avoid the need for additional handling while sorting and packing the fruits. With respect to post-harvest techniques, pre-cooling methods, cold chain processes, and highly improved packages have been developed. In particular, the use of hammocktype and elastic film packages mean the strawberry fruit does not make contact with other fruits or trays. These packages also change the acceleration transmissibility under vibration, which can further prevent damage to the fruits during long-term transport. These emerging varieties, pre-cooling and cold-chain processing, and innovative packages are all compatible with sorting and packing robots, allowing for full integration of these processes. Therefore, these innovations and continuous improvements in breeding and packaging are expected to increase the export of Japanese strawberry fruits and provide guidance for achieving a balance between long shelf-life and high palatability in global strawberry production.
\end{abstract}

Key Words: firmness, improved packages, pectin, texture.

\section{Introduction}

Strawberry (Fragaria $\times$ ananassa Duch.) fruit is highly perishable, requiring innovative methods to extend the shelf-life without compromising palatability. Indeed, conventional decay-control treatments can effectively enhance the firmness of the fruit, but can also result in loss of fruit quality or flavor. For example, the use of edible coating and carbon dioxide treatments decreases or transforms the off-flavors due to the inhibition of oxygen exchange by the thick edible coating, or an increase in ethyl acetate and ethyl butyrate and a decrease in other alcohols following carbon dioxide treatments (Ke et al., 1994; Larsen and Watkins, 1995; Pérez and Sanz, 2001; Raghav et al., 2016; Ueda and

Received; August 29, 2019. Accepted; December 24, 2019.

First Published Online in J-STAGE on April 6, 2020.

Special Issue "Strawberry".

* Corresponding author (E-mail: mhikawa@affrc.go.jp).
Bai, 1993; Vargas et al., 2008). In addition, increasing the hardness of an object typically reduces its flavor intensity, which is also the case for strawberry fruits (Calviño et al., 1993; Cook et al., 2003; Morishita et al., 1997). Therefore, several approaches have been developed to extend the shelf-life of strawberries without losing palatability, especially in terms of enhancing production for the global fresh market.

Japanese strawberries are particularly well-known for their juicy texture and sweetness, and can serve as a useful model for strawberry production worldwide. Ever since strawberries were first introduced to Japan in the $19^{\text {th }}$ century, consumer preference and therefore breeding have focused on achieving a heavy fruit weight, delicious flavor, and high sugar-acid ratio, resulting in the development of varieties with high palatability (Morishita, 1994). Indeed, these berries are so juicy that they are often associated with the Japanese terms "Guchogucho" or "guchox", onomatopoeic expressions of texture for very soft and watery foods 
(Hayakawa et al., 2011). The great taste and texture of these varieties are prioritized above all, and require breeding and technological developments.

Accordingly, the present review focuses on the breeding strategies and post-harvest technique developments for Japanese strawberries with an emphasis on the unique breeding characteristics of varieties designed to be firm to the touch, but as soft as possible in texture, as well as techniques for preservation, including the design of highly improved packages. The aim of this review is to provide support for strawberry production by achieving a balance of long shelf-life and high palatability.

\section{Breeding of Varieties with a Long Shelf-life}

Table 1 and Figure 1 show the main varietal characteristics associated with the shelf-life and palatability of Japanese strawberry varieties compared to those of other varieties. Individual evaluation data of Japanese and global accessions are available from the Genebank Project, NARO (https://www.gene.affrc.go.jp/index_en. php).

\section{Cell wall pectin design}

Strawberry fruits have a large cell size with a thin

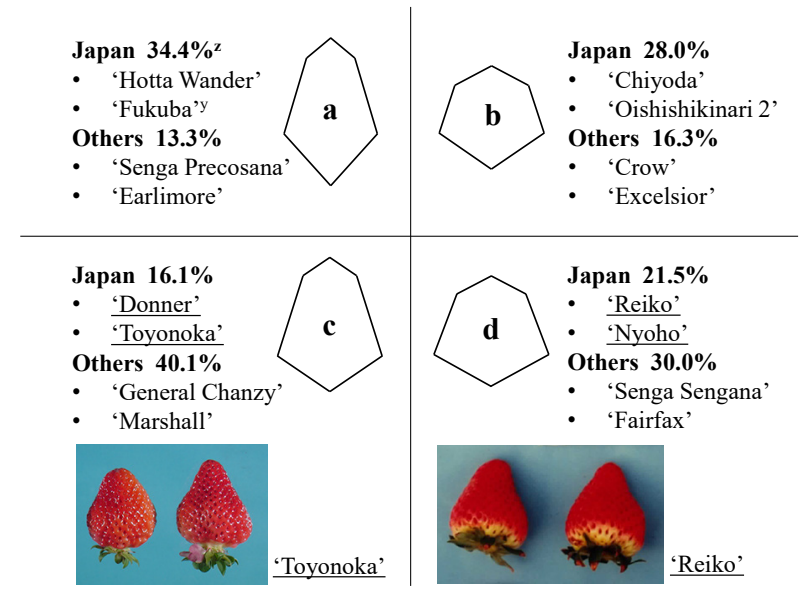

Fig. 1. Fruit shape and representative examples of Japanese and other strawberry varieties. Underlined varieties are those established under forcing culture in Japan; they were improved to have a lower center of gravity compared to North American or European varieties. ${ }^{\mathrm{z}}$ Percentage in 93 Japanese varieties and 98 North American or European varieties investigated. ${ }^{y}$ the oldest Japanese variety breed from 1898. (a) Long-coned fruit with a high center of gravity and short diameter at $5 \mathrm{~mm}$ below the tip. (b) Short-coned fruit with a high center of gravity and long diameter at $5 \mathrm{~mm}$ below the tip. (c) Long-coned fruit with a low center of gravity and a short diameter at $5 \mathrm{~mm}$ below the tip. (d) Short-coned fruit with a low center of gravity and long diameter at $5 \mathrm{~mm}$ below the tip (Adapted from Morishita [1994]).

Table 1. Fruit characteristics of Japanese strawberry varieties compared to other varieties.

\begin{tabular}{|c|c|c|c|c|c|}
\hline Traits & Evaluation index & $\begin{array}{l}\text { Characteristics compared to } \\
\text { standards }\end{array}$ & $\begin{array}{c}\text { Number of } \\
\text { Japanese varieties } \\
\text { investigated }\end{array}$ & $\begin{array}{l}\text { Number of standard } \\
\text { varieties compared }\end{array}$ & References \\
\hline \multirow{3}{*}{ Hardness } & fruit firmness & the same & 104 & $\begin{array}{l}70 \text { North American and } \\
36 \text { European }\end{array}$ & Morishita, 1994 \\
\hline & skin and flesh firmness & $\begin{array}{l}\text { intermediate between North } \\
\text { American and European }\end{array}$ & 16 & $\begin{array}{l}37 \text { North American and } \\
17 \text { European }\end{array}$ & Monma et al., 1977 \\
\hline & $\begin{array}{l}\text { skin and flesh firmness } \\
\text { apparent modulus of } \\
\text { elasticity }\end{array}$ & $\begin{array}{l}\text { mostly the same but some are higher } \\
\text { or lower } \\
\text { mostly the same but some are higher } \\
\text { or lower }\end{array}$ & 39 & $\begin{array}{l}9 \text { from North America } \\
\text { and Europe }\end{array}$ & $\begin{array}{l}\text { Hikawa-Endo et al., } \\
2018\end{array}$ \\
\hline Weight & - & heavier & \multirow{3}{*}{93} & \multirow{3}{*}{$\begin{array}{l}59 \text { North American and } \\
32 \text { European }\end{array}$} & \multirow{3}{*}{ Morishita, 1994} \\
\hline Shape & center of gravity & higher (Fig. 1) & & & \\
\hline Seed position & - & $\begin{array}{l}\text { deeper than North American varieties } \\
\text { and the same as European varieties }\end{array}$ & & & \\
\hline \multirow{8}{*}{ Taste } & $\begin{array}{l}\text { soluble solids content } \\
\mathrm{pH}\end{array}$ & $\begin{array}{l}\text { higher } \\
\text { higher }\end{array}$ & 104 & $\begin{array}{l}70 \text { North American and } \\
36 \text { European }\end{array}$ & Morishita, 1994 \\
\hline & sugar content & the same & \multirow{7}{*}{29} & \multirow{7}{*}{$\begin{array}{l}14 \text { from North America } \\
\text { and Europe }\end{array}$} & \multirow{7}{*}{ Sone et al., 2000} \\
\hline & sucrose ratio & higher & & & \\
\hline & glucose ratio & higher & & & \\
\hline & organic acid content & lower & & & \\
\hline & citric acid ratio & the same & & & \\
\hline & sugar-acid ratio & higher & & & \\
\hline & sucrose-acid ratio & higher & & & \\
\hline Aroma & sensory evaluation & stronger & 104 & $\begin{array}{l}70 \text { North American and } \\
36 \text { European }\end{array}$ & Morishita, 1994 \\
\hline Palatability & $\begin{array}{l}\text { eating quality by sensory } \\
\text { evaluation }\end{array}$ & preferable & 29 & $\begin{array}{l}14 \text { from North America } \\
\text { and Europe }\end{array}$ & Sone et al., 2000 \\
\hline
\end{tabular}


cell wall in most tissue zones, although the cell dimensions vary depending on the zone (Szczesniak and Smith, 1969). These structurally fragile cells are easily pulled apart without breakage by external forces (Harker et al., 2000). This ability for cell wall disassembly and cell adhesiveness are the predominant physical properties of strawberry fruits (Brummell, 2006). The relationships between physiological properties, or cell wall strength and physical properties, in strawberry remain unclear (Harker et al., 2000), although the contribution of water physiological parameters to physical properties has been recognized in carrot tissue (Greve et al., 1994).

Japanese strawberry varieties can be characterized by a unique cell wall pectin constitution that is undoubtedly related to their cell wall disassembly and cell adhesive properties. Indeed, numerous studies have demonstrated that pectin solubility, molecular weight, and cationic stability are all closely related to the physical properties of ripening fruits (Inari and Takeuchi, 1997; Manabe, 1981; Neal, 1965; Redgwell et al., 1997). Differences in cell wall pectin among strawberry varieties are related to the amount and ratio of hydrochloric acid-soluble pectin and hexametaphosphatesoluble pectin (Sato and Narikawa, 1985; Sato and Yamakawa, 1989; Sato et al., 1987). Recently developed major Japanese varieties that are characterized by a long shelf-life have much higher hydrochloric acidsoluble pectin content, exceeding the level of watersoluble pectin or hydrochloric acid-soluble pectin in 'Tochiotome' and 'Reiko', although the content greatly declines during ripening (Kashiwazaki et al., 2007; Sato et al., 1986). The ratio of hydrochloric acid-soluble pectin to holocellulose is an equally important factor contributing to the physical properties of strawberry fruit, and is related to the texture. Pectin solubilization involves migration of water to the empty spaces in the cellulose-xyloglucan network, and is closely related to the melting texture (Redgwell et al., 1997). A ratio of $4.5-5.5 \%$ hydrochloric acid-soluble pectin to holocellulose was determined to be appropriate for improving texture based on a sensory evaluation conducted in Japan (Sato and Yamakawa, 1989). Although ultrathin cellulose can be observed in detail by microscopy (Niimura et al., 2010), little data available on the actual characteristics of cellulose in Japanese strawberry fruits.

\section{Fruit shape and size}

Macroscopic features such as fruit shape and size are also known to affect the shelf-life of strawberry fruits. This is mostly related to the effects of mechanical stress that affect the physical appearance during post-harvest handling.

Some varieties may have an improved shelf-life due to changes in fruit shape, although there is no definitive optimal physical shape. Compression test results showed that the apex, as well as the equatorial part of the fruit, are soft and easily damaged (Konya et al., 2007). Therefore, varieties with a more rounded apex and equatorial parts such as 'Oishi Berry' could be more resistant to physical damage. In addition, fruits with a more rounded and short-coned shape such as 'Koiminori' may be recommended from the viewpoint of achieving both fruit firmness and a juicy texture. Indeed, such shapes are typically associated with flesh with large cells (Szczesniak and Smith, 1969) (Fig. 2). Therefore, such fruits may be juicier overall even if the skin is relatively hard. Further studies on the relationships between fruit shape and palatability are required to understand these effects given the limited reports on the relationships between fruit shape and water, soluble solid, and acid content (Morishita, 1994).

Japanese strawberry varieties are genetically large (Morishita, 1994), and this is not a favorable property in terms of shelf-life, since large fruit can often collapse under their own weight. In addition, large fruits are often more difficult to handle because of the axisdistorted shape that accompanies extreme enlargement (Katayama et al., 2003). An additional challenge is the uniformity of fruit size, which is related to morphological inflorescence characteristics. Most Japanese varieties are under forced culture and bred to flower continuously, resulting in a short pedicle length and short diameter, leading to considerable variation in fruit size (Sone et al., 2004; Takeuchi, 1993). For this reason, 'Fukuoka S7' and 'Tochiotome', with average fruit weights of around $25 \mathrm{~g}$ and $15 \mathrm{~g}$, respectively, can collapse from their own weight (Ishihara et al., 1996; Mitsui et al., 2003). Recent varieties were established to increase the pedicle length and diameter to achieve a more uniform fruit shape, including 'Ookimi' and 'Koiminori' originally derived from 'Satsumaotome'. These uniformly large-sized, well-shaped varieties with improved physical properties are easy to handle and do not require further manipulation in post-harvest processes (Hikawa-Endo, 2018; Fig. 3).

The presence of cavities has been associated with transportability in watermelon fruits (Andus, 1949), al-

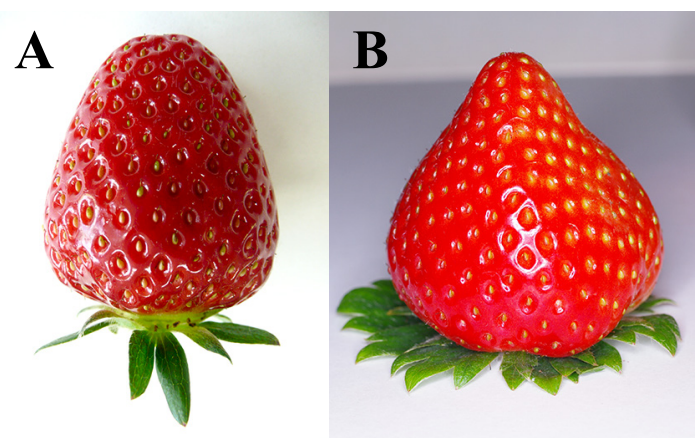

Fig. 2. 'Oishi Berry' with a rounded apex and equatorial parts (A), and 'Koiminori' with a rounded and short-coned shape (B). 

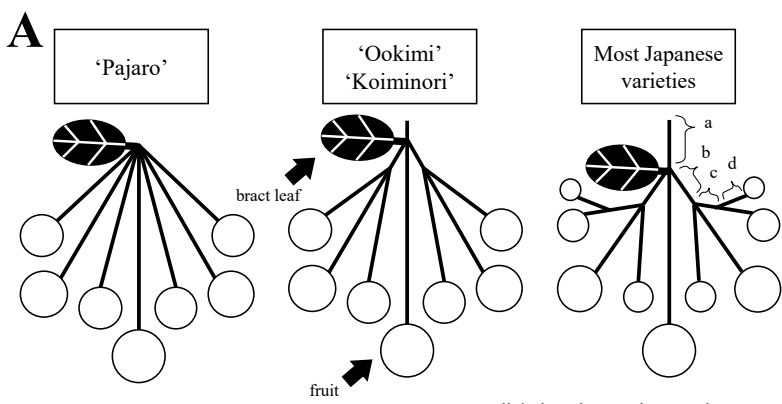

pedicle length $=\mathrm{a}+\mathrm{b}+\mathrm{c}+\mathrm{d}$

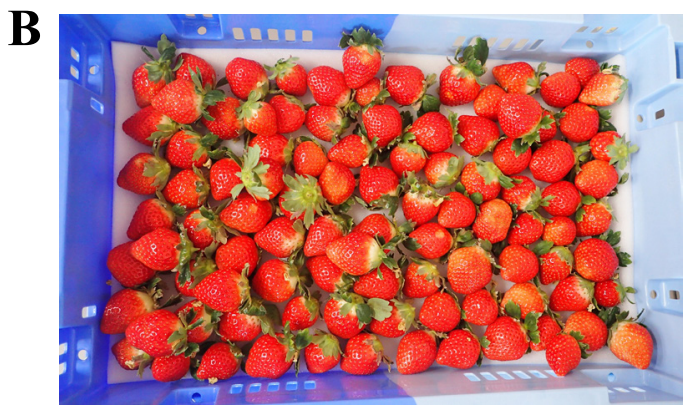

Fig. 3. Morphological inflorescence characteristics of 'Ookimi' and 'Koiminori' (A), and unsorted but orderly 'Koiminori' fruits (B). Adapted from Sone et al. (2004).

though there has been little study of this relationship in strawberry fruits. The cavity size of strawberry fruit is contingent on the fruit size, and this is closely linked to the variety. Although some of the larger-sized varieties also have larger cavities, support for the relationship between physical properties and cavity size remains inconclusive (Darrow, 1966; Kamoshita and HikawaEndo, 2018).

\section{Comprehensive evaluation of physical properties}

The impact of the features described above on the physical properties of Japanese strawberry fruits needs to be comprehensively evaluated using several indices.

For example, the instrumental compression test method was established in the 1970s to distinguish the skin and flesh firmness according to the penetration resistance using a universal testing machine with a discshaped plunger of 2-3-mm diameter (Monma et al., 1977). Based on this method, skin firmness was found to have a greater contribution to shelf-life than flesh firmness, although skin firmness, reduction in flesh firmness, and an increase in penetration deformation were all correlated with shelf-life (Mochizuki et al., 2001; Monma and Kamimura, 1978). These studies motivated some Japanese breeders to produce varieties with greater skin firmness, but only moderate flesh firmness. Skin and flesh firmness are genetically independent traits (Monma and Kamimura, 1985), although they show phenotypic correlations owing to cell-level changes during ripening (Mochizuki et al., 2001; Monma and Okitsu, 1987; Monma et al., 1977; Mori, 2000). In breeding, the use of a universal testing ma-

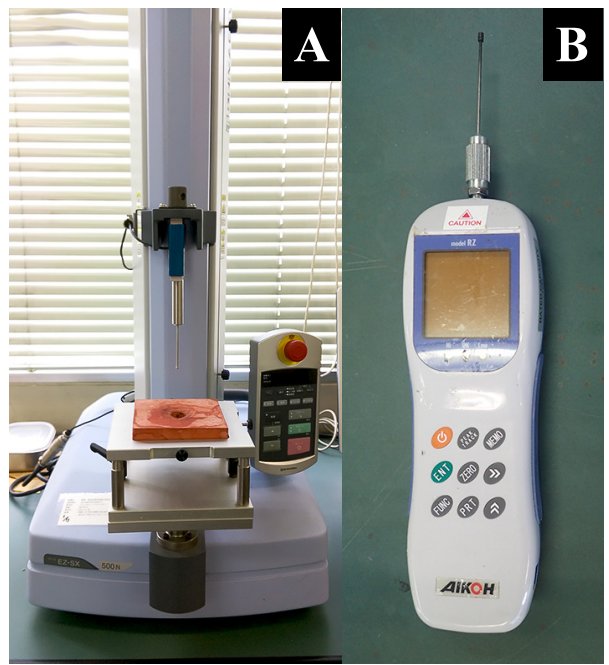

Fig. 4. Universal testing machine (A) and push-pull gauge (B).

chine has largely been replaced by a push-pull gauge, which is a small, portable instrument (Monma et al., 1977) that is more convenient for measuring skin and flesh firmness for primary selection. Recent major cultivars developed under forcing culture such as 'Tochiotome' and 'Fukuoka S6' were bred according to their firmness properties measured using a push-pull gauge (Ishihara et al., 1996; Mitsui et al., 2003) (Fig. 4).

Another useful index of the physical properties of strawberry fruits is the apparent modulus of elasticity; this is a mechanical parameter defined by the maximum slope of the compression load-strain curve before the break point. This index can clearly reflect varietal differences and post-harvest changes (Hikawa-Endo et al., 2018; Kohyama et al., 2013). The apparent modulus of elasticity is also strongly correlated with skin firmness, although some cultivars have high skin firmness but a low apparent modulus of elasticity, and vice versa (Hikawa-Endo and Sone, 2019; Hikawa-Endo et al., 2018). Such exceptions may be related to variations in fruit shape, because the compression strain is dependent on the fruit diameter. For example, 'Koiminori', a variety with a large diameter, has a quite high apparent modulus of elasticity. Since the heritability of the apparent modulus of elasticity is usually higher than that of skin or flesh firmness, it is considered to be a useful selection index for varieties with preferable physical properties (Hikawa-Endo and Sone, 2019).

\section{Development of Post-harvest Decay-control Techniques in Japan}

\section{Importance of post-harvest techniques in Japan}

In addition to the intrinsic biological characteristics highlighted in the section above, abiotic factors such as temperature, humidity, and irrigation during cultivation or distribution greatly affect the physical properties of strawberry fruits (Aoyagi and Makino, 1981; Darrow, 
1966; Noguchi, 2002). Moreover, several fruits are latently infected by Botrytis cinerea and Cladosporium spp. throughout the harvest period, which can influence the final quality (Aikawa et al., 2008; Ishizaka and Takahashi, 1997). Therefore, despite achieving good improvements in strawberry varieties, appropriate postharvest treatment is also essential given the high temperature and humidity in Japan, particularly in greenhouses during the hot seasons. This section provides an overview of some of the post-harvest decaycontrol techniques that have been developed and employed with relatively minimal impact on the final palatability of strawberry fruits.

\section{Pre-cooling and cold-chain processes}

Some of the most widely used, but important, decaycontrol techniques are pre-cooling and cold-chain processing. The cellular respiration and pectin behaviors described above are suppressed under low-temperature conditions; therefore, pre-cooling and application of a cold chain are essential to prevent physical damage, physiological loss, and mold growth due to vibrations during transport, as well as human manual manipulation such as during packing. In strawberry fruits, the temperature coefficient $\left(\mathrm{Q}_{10}\right)$, representing the change in the respiration rate with a $10^{\circ} \mathrm{C}$ difference in temperature, is around 2.7 (Liu and Kojima, 1997). The distribution temperature of strawberry fruit should be as low as possible, although it must be higher than the freezing point of around $-1{ }^{\circ} \mathrm{C}$ (Maezawa and Akimoto, 1995; Wang et al., 1988). The most suitable pre-cooling method for strawberry fruits has been established to be forced draft pre-cooling (Hasegawa, 1998).

Several studies have reported that the use of precooling and a cold chain do not compromise the flavor of strawberry fruits. Maezawa and Akimoto (1995) showed that the taste of pre-cooled fruits was superior to that of control fruits regardless of the stage of maturity. Another study showed that the taste of pre-cooled or cold-stored ripe fruits was superior to that of control unripe fruits, especially for high acidity varieties (Aoyagi and Makino, 1981; Ishii, 1994). These effects are mainly attributed to the following factors: (1) precooling and a cold chain enable the distribution of fully ripe fruits with a high soluble solid content and low acid content, (2) a low temperature reduces the decrease in the soluble solid content by respiration during postharvest, and (3) pre-cooling and a cold chain do not promote the generation of ethyl esters, as described in the next section.

\section{Highly improved packages}

Kitazawa and colleagues (Kitazawa and Saito, 2014; Kitazawa et al., 2012) proposed a useful damage estimation theory considering cumulative fatigue. Specifically, they demonstrated that the relationship between shock acceleration and frequency of damage occurrence to strawberry fruits could be represented by a power approximation curve. The curve depends on the firmness of the fruit, as well as the packaging, and demonstrated that conventional trays are not adequate to prevent damage (Kitazawa et al., 2010a, b). These trays do not easily absorb vibrations and shocks incurred during transport, which can result in fruit jumping and rotation, as well as an increase in respiratory volume. In particular, fruit damage in these trays is worse under horizontal vibrations than vertical vibrations, and with front-toback vibrations compared to left-to-right vibrations (Nakamura et al., 2007; Tatara et al., 1999). Another disadvantage of these trays is that the fruit is in contact with other fruits or trays, which increases the opportunity for damage and mold, especially at the contact areas (Aikawa et al., 2008).

Therefore, perforated polyethylene (PE) or polystyrene (PS) trays have been introduced as improved packaging designs. These include hole-type packages, hammock-type packages, and elastic film packages, which have a buffering effect and can effectively separate fruits from each other (Fig. 5). The acceleration transmissibility at the center of packages is highly correlated with the package performance, as these packages can change the acceleration transmissibility under vibrations to prevent damage to the fruits. A hole-type package contains fruit-shaped holes at regular intervals in a foamed PS tray and is effective at reducing damage occurrence at $0.6 \times \mathrm{g}$ within $1 \mathrm{~h}$; however, these packages cannot prevent damage occurrence under long distance transportation (Baba et al.,

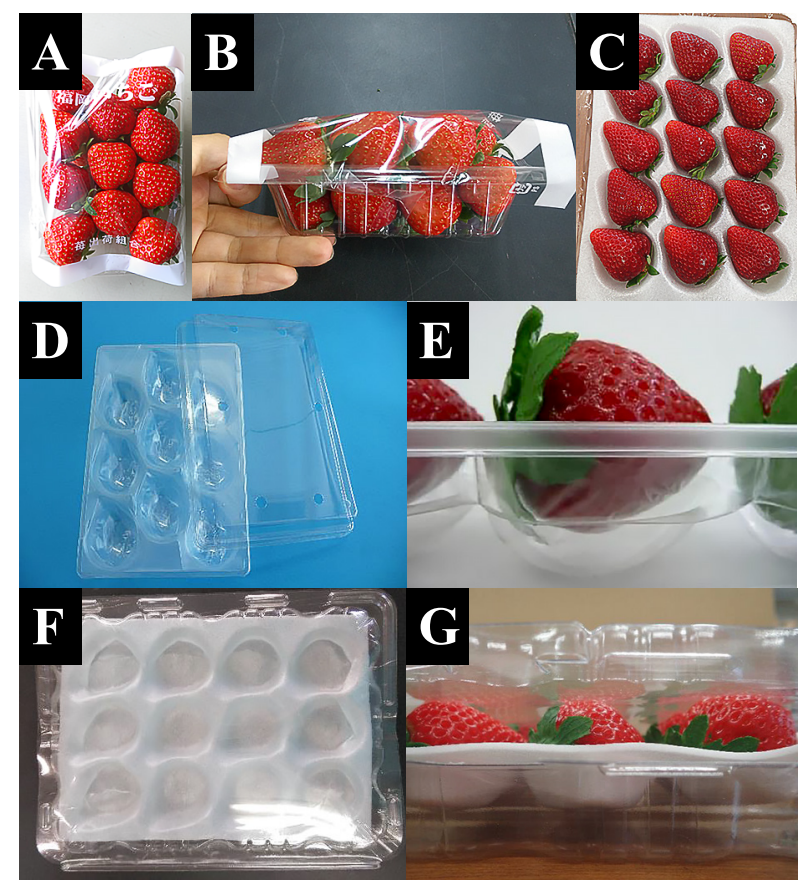

Fig. 5. Conventional tray (A, B) and improved packages, including (C) a hole-type package, (D, E) hammock-type packages, and (F, G) elastic film packages for strawberry fruit. 
2012; Kitazawa et al., 2010b; Nakamura et al., 2008). A hammock-type package is more effective in preventing damage under long distance transportation, as the fruits are wrapped in a flexible PE film and float without making contact with the hard polyethylene terephthalate (PET) outer trays in the package; therefore, acceleration transmissibility and damage occurrence are greatly affected by the thickness of the PE film (Baba et al., 2012; Kuruma et al., 2010). An elastic film package is also effective for long distance transportation as it forms a PE film air cap inside to hold the strawberry fruits, thereby preventing their rotation (Hikawa-Endo and Sone, 2017). Since the fruits are wrapped in a PE film and a PET tray, improvements in air permeability are an important consideration for hammock-type and elastic film packages. Ventilation holes are made in the PET trays to prevent condensation and mold generation (Eshima et al., 2012). The optimal package depends on the properties of the variety; therefore, package selection is just as important as variety selection. For example, a hammock-type package may not be suitable for softer varieties because it cannot hold the fruits as firmly as elastic film packages and allow fruit rotation (Hikawa-Endo and Sone, 2017).

For long distribution routes such as sea transport, modified atmosphere packaging (MAP) is additionally used to improve packages. As mentioned above, since a high concentration of carbon dioxide can decrease or transform the off-flavor, it is important to maintain the carbon dioxide concentration below 4.7-6.9\% with the practical use of MAP. Zeolite and larger capacity bags are effective in preventing an excessive rise in carbon dioxide concentrations (Iimura et al., 2017). Although such packaging can prevent skin discoloration by suppressing respiration, the damage occurrence prevention ability is considerably inferior compared to that of the improved packages mentioned above. The skin of some varieties seldom discolors even after a long time. Thus, the containers used for strawberry packaging are considered to be a higher priority than MAP (Hikawa-Endo and Sone, 2017).

Carbon dioxide emissions during the production of some types of these packages have also been investigated, and these are estimated to be 2-3 times those of conventional trays. Although manufacturing of new packages requires a large amount of plastic, the reduction in food loss with the new packages during distribution results in an overall carbon dioxide reduction effect of up to $27 \%$ (Oishi et al., 2009). Life cycle assessments in the development of strawberry packages are expected to increase in the near future.

\section{Sorting and packing}

A strawberry sorting system with a non-destructive analyzer using a light sensor is a popular labor-saving technology used in packaging centers in Japan. This system contains a pan with a hole to arrange and main- tain strawberry fruits with similar measurements in the same position (Yamada and Arao, 2010). Image capture and processing are also implemented for sorting (Ikegaya et al., 2019). With respect to packing, robots have also been developed for picking and holding the fruits by the calyx using vacuum-based hands. Some of the improved packages are compatible with packing robots since they have equally spaced fruit-shaped holes. Since the mishandling rate in these robots is affected by fruit size, shape, and uniformity (Yamamoto et al., 2015), parallel breeding may effectively increase the efficiency of these robots. Although not yet examined, robots are expected to be able to work under lowtemperature conditions, which could further help to maintain the cold chain. Thus, the breeding, cold chain, and highly improved packages developed to date can be supported by robots to realize an integrated post-harvest fruit system in the near future.

\section{Conclusion and Perspectives}

Although strawberry fruits are highly perishable, it is possible to improve their shelf-life without losing palatability based on careful studies and selection of appropriate traits, packaging, and processing techniques. Since physical properties are related to both the texture and shelf-life of the fruit, it is difficult to completely separate these effects. However, improvements in various traits such as the pectin and cellulose composition, along with fruit shape, size, and uniformity can help to balance the palatability and shelf-life of strawberry fruits. In Japan, it is expected that this balances will be further advanced, and more palatable strawberries will be distributed over greater distances and with longer transport times in the near future.

However, there are still some issues to be overcome. For example, exports of agricultural products, including strawberries, are rapidly being promoted in Japan at present. Strawberry fruits are typically transported with other fruits and vegetables that have different optimal storage temperatures; therefore, applied research focusing on not only strawberries, but also various other agricultural products that are exported together is required. In this regard, development of a novel shipping container with dual temperature spaces has already begun. It is equally important to focus on more efficient distribution processes. For example, the cold chain is sometimes broken during international customs clearance or quarantine. Therefore, developments in international trade systems and cooperation when transporting strawberry fruits are needed in addition to further developments in breeding and post-harvest techniques.

\section{Literature Cited}

Aikawa, K., Y. Asai and T. Takahashi. 2008. Mold growth on strawberries and cherries during storage at $25^{\circ} \mathrm{C}$. Food Hyg. Safe. Sci. 49: 106-110 (In Japanese with English abstract).

Andus, C. F. 1949. Factors influencing breakage resistance in 
watermelons. Proc. Amer. Soc. Hort. Sci. 53: 319-322.

Aoyagi, M. and H. Makino. 1981. Effect of maturity at the harvest and low temperature distribution on keeping quality of strawberry fruits. J. Japan. Soc. Hort. Sci. 49: 583-591 (In Japanese with English abstract).

Baba, N., A. Eshima, T. Ooishi, T. Orino, M. Kuruma, S. Yasutake, Y. Miyazaki, M. Kabashima and K. Watanabe. 2012. Development of a hammock-type package for strawberries. (1) Damage-prevention effect of the hammock-type package. Bull. Fukuoka Agric. Res. Cent. 31: 27-31 (In Japanese with English Abstract).

Brummell, D. A. 2006. Primary cell wall metabolism during fruit ripening. New Zealand J. Forest. Sci. 36(1): 99-111.

Calviño, A. M., M. R. García-Medina, J. E. Cometto-Muñiz and M. B. Rodríguez. 1993. Perception of sweetness and bitterness in different vehicles. Percept. Psychophys. 54: 751758.

Cook, D. J., T. A. Hollowood, R. S. T. Linforth and A. Taylor. J. 2003. Oral shear stress predicts flavor perception in viscous solutions. Chem. Senses 28: 11-23.

Darrow, G. M. 1966. Morphology and Physiology. p. 314-354. In: The Strawberry. Holt, Rinehart and Winston. N. Y., Chicago and San Francisco.

Eshima, A., N. Baba, T. Ooihi and T. Orino. 2012. Development of hammock-type packages for strawberries. (2) Improvement of permeability. Bull. Fukuoka Agric. Res. Cent. 31: 32-35 (In Japanese with English Abstract).

Greve, L. C., K. A. Shackel, H. Ahmadi, R. N. McArdle, J. R. Gohlke and J. M. Labavitch. 1994. Impact of heating on carrot firmness: contribution of cellular turgor. J. Agr. Food Chem. 42: 2896-2899.

Harker, F. R., H. J. Elgar, C. B. Watkins, P. J. Jackson and I. C. Hallett. 2000. Physical and mechanical changes in strawberry fruit after high carbon dioxide treatments. Postharvest Biol. Technol. 19: 139-146.

Hasegawa, Y. 1998. New technology of the post-harvest fresh keeping on fruits and vegetables. J. Jpn. Soc. Agric. Mach. 60: 174-180 (In Japanese).

Hayakawa, F., Y. Kazami, K. Ioku, S. Akuzawa, K. Nishinari and K. Kohyama. 2011. Collection and analysis of foods associated with Japanese texture terms. Nippon Shokuhin Kagaku Kogaku Kaishi 58: 359-374 (In Japanese with English Abstract).

Hikawa-Endo, M. 2018. Novel packaging of strawberry fruits for sea transport and its related aspects. J. Pack. Sci. Technol. 27: 13-20 (In Japanese with English abstract).

Hikawa-Endo, M. and K. Sone. 2017. Evaluation of novel packages and modified atmosphere packaging for the reduction of damage to strawberry fruits during air or sea transport. Hort. Res. (Japan) 16: 95-104 (In Japanese with English abstract).

Hikawa-Endo, M. and K. Sone. 2019. Availability of apparent modulus as selection index of strawberry considering relationship to damage occurrence and genetic characteristics. Breed. Res. 21: 20-27 (In Japanese with English abstract).

Hikawa-Endo, M., K. Sone, T. Fujita and M. Morishita. 2018. Changes in the apparent modulus of elasticity of strawberries during storage and harvest periods, and evaluation of the apparent modulus of elasticity in different strawberry cultivars. Bull. NARO Agr. Res. Kyushu Okinawa Reg. 67: 1-14 (In Japanese with English abstract).

Iimura, K., T. Oohashi, Y. Kobayashi, Y. Oohashi, T. Shigeno and T. Nakanishi. 2017. Establishment of freshness and quality maintenance technology for long-distance transportation of strawberry. Bull. Tochigi Agr. Exp. Stn. 75: 45-53 (In
Japanese with English abstract).

Ikegaya, A., M. Mochizuki, H. Amaike, T. Kawata, T. Ikari, S. Ohba, T. Takeuchi, S. Ito and E. Arai. 2019. Development and performance evaluation of strawberry class sorting apparatus for improvement of packaging center efficiency. Hort. Res. (Japan) 18: 73-79 (In Japanese with English abstract).

Inari, T. and T. Takeuchi. 1997. Changes in pectic substances during the ripening of strawberry fruit. Nippon Shokuhin Kagaku Kogaku Kaishi 44: 319-324 (In Japanese with English abstract).

Ishihara, Y., K. Takano, M. Ueki and H. Tochigi. 1996. New strawberry cultivar 'Tochiotome'. Bull. Tochigi Agr. Exp. Stn. 44: 109-123 (In Japanese with English abstract).

Ishii, K. 1994. Studies on precooling of fruits and vegetables. Spec. Bull. Chiba-Ken Agric. Exp. Station 26: 1-95 (In Japanese with English abstract).

Ishizaka, N. and K. Takahashi. 1997. Latent infection of Botrytis cinereal causing strawberry gray mold. Ann. Rept. Plant Prot. North Japan. 48: 88-90 (In Japanese).

Kamoshita, A. and M. Hikawa-Endo. 2018. Effect of cavity on physical properties of strawberry fruit. Hort. Res. (Japan) 17 (Suppl. 2): 176 (In Japanese).

Kashiwazaki, M., T. Nahasue, H. Soutome, M. Nakajima and S. Omori. 2007. Non-destructive measurement of strawberry fruit firmness (Part 1) Relationship between strawberry fruit firmness and the cell wall constituent pectin. J. Jpn. Soc. Agric. Mach. 69: 49-56 (In Japanese with English abstract).

Katayama, T., K. Imou, T. Okamoto, Y. Kaizu and K. Tsukano. 2003. Discrimination of strawberry class using 3D image processing. J. Jpn. Soc. Agric. Mach. 65: 71-76 (In Japanese with English abstract).

Ke, D., L. Zhou and A. A. Kader. 1994. Mode of oxygen and carbon dioxide action on strawberry ester biosynthesis. J. Am. Soc. Hort. Sci. 119: 971-975.

Kitazawa, H. and K. Saito. 2014. Construction of a new damage estimation theory for fresh produce with consideration of cumulative fatigue 2. Effect of repetitive shock on damage to strawberry fruit. J. Pack. Sci. Technol. 23: 277-285 (In Japanese with English abstract).

Kitazawa, H., Y. Ishikawa, F. Lu, Y. Hu, N. Nakamura and T. Shiina. 2010a. Analysis of shock during strawberry transport and damage estimation. Hort. Res. (Japan) 9: 221-227 (In Japanese with English abstract).

Kitazawa, H., T. Sato, Y. Ishikawa, N. Nakamura and T. Shiina. 2010b. Effect of shock on the damage occurrence of strawberry packaged by foam fruit tray. Food Preserv. Sci. 36(6): 265-269 (In Japanese with English abstract).

Kitazawa, H., T. Sato, N. Hasegawa, Y. Li and Y. Ishikawa. 2012. Construction of a new damage estimation theory for fresh produce with consideration of cumulative fatigue 1. Damage occurrence in strawberry subjected to repetitive shock. J. Pack. Sci. Technol. 21: 125-132 (In Japanese with English abstract).

Kohyama, K., T. Masuda, H. Shimada, T. Tanaka and Y. Wada. 2013. A simple mechanical index of storage quality of strawberry fruits. Rep. Nat'l Food Res. Inst. 77: 1-11.

Konya, T., S. Omori and S. Hayashi. 2007. Study on quality preservation technology of strawberries (Part 1) -Firmness property and effect of load on quality of strawberries-. J. Jpn. Soc. Agric. Mach. 69: 67-74 (In Japanese with English abstract).

Kuruma, M., S. Yasutake, T. Ooishi, T. Orino, N. Baba, Y. Miyazaki and T. Matsumoto. 2010. Package design for longdistance transport of strawberries "Amaou" produced in Fukuoka Prefecture. 57th Annu. Confer. JSSD. G01 (In 
Japanese with English abstract).

Larsen, M. and C. B. Watkins. 1995. Firmness and concentrations of acetaldehyde, ethyl acetate and ethanol in strawberries stored in controlled and modified atmospheres. Postharvest Biol. Tech. 5: 39-50.

Liu, J. Y. and T. Kojima. 1997. Effects of vibration and storage temperatures on quality of strawberries. J. Soc. Agric. Struc., Japan 28: 135-142 (In Japanese with English abstract).

Maezawa, S. and K. Akimoto. 1995. Effects of pre-cooling conditions on post-harvest qualities of strawberries with different maturity levels. Res. Bull. Fac. Agr. Gifu Univ. 60: 65-73 (In Japanese with English abstract).

Manabe, M. 1981. Firmness and pectic substances of fruit tissue. Nippon Shokuhin Kagaku Kogaku Kaishi 28: 653-659 (In Japanese with English abstract).

Mitsui, H., K. Fujita, T. Sueyoshi and H. Fushihara. 2003. New strawberry cultivar 'Fukuoka S 6' and 'Fukuoka S 7' for forcing culture. Bull. Fukuoka Agric. Res. Cent. 22: 61-68 (In Japanese with English abstract).

Mochizuki, T., Y. Inagawa, E. Funakura, Y. Noguchi and K. Sone. 2001. Evaluation methods of varietal differences in keeping quality of forcing strawberry fruit. Bull. Veg. Ornam. Crop Res. Station 16: 1-7 (In Japanese with English abstract).

Monma, S. and S. Kamimura. 1978. The varietal differences in shelf-life and its controlling factors of strawberry fruit. Bull. Veg. Ornam. Crop Res. Station Ser. B 2: 1-10 (In Japanese with English abstract).

Monma, S. and S. Kamimura. 1985. Inheritance of fruit firmness in strawberry (Fragaria $\times$ ananassa Duch.). Bull. Veg. Ornam. Crop Res. Station Ser. B 5: 49-59 (In Japanese with English abstract).

Monma, S. and S. Okitsu. 1987. Varietal differences of soluble solids, acidity and the soluble solids-acid ratio and relationships between these characteristics, yield components and vegetative characteristics in strawberry (Fragaria $\times$ ananassa Duch.). Bull. Veg. Ornam. Crop Res. Station Ser. B 7: 11-19 (In Japanese with English abstract).

Monma, S., S. Kamimura and H. Yoshikawa. 1977. Measuring textural characteristics of strawberry fruit using the autograph and push-pull gauge. Bull. Veg. Ornam. Crop Res. Station Ser. B 1: 1-11 (In Japanese with English abstract).

Mori, T. 2000. Heritability and selection effectiveness for fruit firmness in strawberry. J. Japan. Soc. Hort. Sci. 69: 90-96 (In Japanese with English abstract).

Morishita, M. 1994. Studies on genetic variation and inheritance of quality and yield characters for advanced strawberry breeding. Bull. Veg. Ornam. Crop Res. Station Ser. A 8: 153 (In Japanese with English abstract).

Morishita, M., T. Mochizuki, Y. Noguchi, K. Sone and O. Yamakawa. 1997. 'Sachinoka', a new strawberry variety for forcing culture. Bull. Veg. Ornam. Crop Res. Station 12: 91115 (In Japanese with English abstract).

Nakamura, N., H. Umehara, D. Nei, H. Okadome, Y. Ishikawa, K. Nakano, S. Maezawa and T. Shiina. 2008. Effects of package conditions on the damage of strawberries. J. Soc. Agric. Struc., Japan 39: 1-8 (In Japanese with English abstract).

Nakamura, N., H. Umehara, H. Okadome, K. Nakano, S. Maezawa and T. Shiina. 2007. Effects of vibration frequency and direction on damage of strawberries. J. Soc. Agric. Struc., Japan 38: 101-108 (In Japanese with English abstract).

Neal, G. E. 1965. Changes occurring in the cell walls of strawberries during ripening. J. Sci. Food Am. 16: 604-611.

Niimura, H., T. Yokoyama, S. Kimura, Y. Matsumoto and S.
Kuga. 2010. AFM observation of ultrathin microfibrils in fruit tissues. Cellulose 17: 13-18.

Noguchi, Y. 2002. Studies on the stabilization of strawberry forcing culture and breeding of adaptable cultivars in the warmer region of Japan. Bull. Nat. Inst. Veg. Tea Sci. 1: 37-95 (In Japanese with English abstract).

Oishi, T., T. Matsumoto, Y. Sewaki, N. Baba, A. Eshima, T. Shiraishi, R. Shintani and N. Shiiki. 2009. Evaluation of function and environmental load of packages for agricultural products by using subminiature censers. Abst. ILCAJ meet. 4th: 10 (In Japanese).

Pérez, A. G. and C. Sanz. 2001. Effect of high-oxygen and highcarbon-dioxide atmospheres on strawberry flavor and other quality traits. J. Agr. Food Chem. 49: 2370-2375.

Raghav, P. K., N. Agarwal and M. Saini. 2016. Edible coating of fruits and vegetables: a review. Int. J. Sci. Res. Modern Edu. 1(1): 188-204.

Redgwell, R. J., E. MacRae, I. Hallett, M. Fischer, J. Perry and R. Harker. 1997. In vivo and in vitro swelling of cell walls during fruit ripening. Planta 203: 162-173.

Sato, Y. and T. Narikawa. 1985. Breeding strawberry for fruit quality. 1. Relation of pectic substances to fruit firmness. Kyushu Agric. Res. 47: 218 (In Japanese).

Sato, Y. and O. Yamakawa. 1989. Evaluation and selection method for fruit quality in strawberry breeding. Bull. Veg. Ornam. Crop Res. Station Ser. D 2: 19-27 (In Japanese with English abstract).

Sato, Y., O. Yamakawa and F. Honda. 1986. Varietal differences in fruit quality during ripening of strawberry. Bull. Veg. Ornam. Crop Res. Station Ser. C 9: 23-30 (In Japanese with English abstract).

Sato, Y., O. Yamakawa and Y. Noguchi. 1987. Strawberry breeding for fruit quality. 3. Relationship of pectic substances and crude holocellulose to fruit texture. Kyushu Agric. Res. 49: 218 (In Japanese).

Sone, K., T. Mochizuki and Y. Noguchi. 2000. Relationship between stability of eating quality of strawberry cultivars and their sugar and organic acid contents. J. Japan. Soc. Hort. Sci. 69: 736-743 (In Japanese with English abstract).

Sone, K., M. Okimura, T. Mochizuki, Y. Noguchi and E. Kitadani. 2004. Relationship between the inflorescence characteristics and fruit size and uniformity of fruit for laborsaved of harvesting and preparation in strawberry. Hort. Res. (Japan) 3: 137-142 (In Japanese with English abstract).

Szczesniak, A. S. and B. J. Smith. 1969. Observations on strawberry texture a three-pronged approach. J. Texture Studies 1: 65-89.

Takeuchi, T. 1993. Relationships between the characteristics of inflorescence and yield components in strawberry. Bull. Shizuoka Agr. Exp. Stn. 37: 41-52 (In Japanese with English abstract).

Tatara, I., T. Tsuji, H. Mikuriya, M. Tanaka, J. Y. Liu, T. Kojima and H. Ohta. 1999. Effect of vibration by simulated transportation on respiration rate and quality of strawberry fruits. Food Preserv. Sci. 25: 15-20 (In Japanese with English abstract).

Ueda, Y. and J. Bai. 1993. Effect of short term exposure of elevated $\mathrm{CO}_{2}$ on flesh firmness and ester production of strawberry. J. Japan. Soc. Hort. Sci. 62: 457-464.

Vargas, M., C. Pastor, A. Albors, A. Chiralt and C. GonzálezMartínez. 2008. Development of edible coatings for fresh fruits and vegetables: possibilities and limitations. Fresh Prod. 2: 32-40.

Wang, H., H. Gemma and C. Oogaki. 1988. Physiological characteristics and keeping qualities on the strawberry and kiwi- 
fruits during chilled storage. J. Jpn. Soc. Cold Preserv. Food 14: 8-14 (In Japanese with English abstract).

Yamada, H. and K. Arao. 2010. An introduction of the YANMAR fruit grading and sorting system. Eco-Eng. 22: 35-38 (In Japanese with English abstract).
Yamamoto, S., S. Hayashi, S. Tsubota, Y. Ochiai, N. Tanaka and H. Yamada. 2015. Development of strawberry-packing robot. J. Jpn. Soc. Agric. Mach. Food Eng. 77: 197-209 (In Japanese with English abstract). 